\title{
Suppression of transforming growth factor- $\beta$ by mesenchymal stem-cells accelerates liver regeneration in liver fibrosis animal model
}

\author{
Nur Anna C Sa'dyah ${ }^{1,4}$, Agung Putra ${ }^{2,45^{*}}$, Bayu Tirta Dirja ${ }^{3}$, Nurul Hidayah', \\ Salma Yasmine Azzahara ${ }^{6}$, and Risky Chandra Satria Irawan ${ }^{2}$
}

ABSTRACT

\section{INTRODUCTION}

Liver fibrosis (LF) results from the unregulated chronic wound healing process in liver tissue. Transforming growth factor-beta (TGF- $\beta$ ) is the major contributing cytokine of LF promotion through activation of quiescent hepatic stellate cells (HSCs) into myofibroblasts (MFs) and increased extracellular matrix (ECM) deposition such as collagen leading to scar tissue development. Mesenchymal stem cells (MSCs) have an immunomodulatory capability that could be used as a new treatment for repairing and regenerating LF through suppression of TGF- $\beta$. This study aimed to examine the role of MSCs in liver fibrosis animal models through suppression of TGF- $\beta$ levels without scar formation particularly in the proliferation phase.

\section{METHODS}

In this study, a completely randomized design was used with sample size of 24. Male Sprague Dawley rats were injected intraperitoneally (IP) with carbon tetrachloride $\left(\mathrm{CCl}_{4}\right)$, twice weekly, for eight weeks to induce LF. Rats were randomly assigned to four groups: negative control, $\mathrm{CCl}_{4}$ group and $\mathrm{CCL}_{4}+\mathrm{MSC}$-treated groups T1 and T2, at doses of $1 \times 10^{6}$ and $2 \times 10^{6}$ cells, respectively. TGF- $\beta$ levels were analyzed by enzyme-linked immunosorbent assay (ELISA). One-way ANOVA and a least significant difference (LSD) was used to analyse the data.

\section{RESULTS}

The TGF levels of LF rat models decreased on day 7 after MSC administration. The levels of TGF- $\beta$ in both MSC groups T1 and T2 decreased significantly compared with the control group $(p<0.05)$. The TGF- $\beta$ suppression capability of T2 was optimal and more significant than that of 1 .

\section{CONCLUSION}

MSCs can suppress TGF levels in liver fibrosis induced rats.

Keywords: Liver fibrosis, mesenchymal stem cells, transforming growth factor- $\beta$, rats

\author{
${ }^{1}$ Department of Internal Medicine, \\ Medical Faculty, Sultan Agung Islamic \\ University Semarang \\ ${ }^{2}$ Stem Cell and Cancer Research \\ (SCCR), Medical Faculty, Sultan \\ Agung Islamic University Semarang \\ ${ }^{3}$ Department of Microbiology, \\ Medical Faculty, Mataram University, \\ West Nusa Tenggara \\ ${ }^{4}$ Department of Postgraduate \\ Biomedical Science, Medical Faculty, \\ Sultan Agung Islamic University, \\ Semarang \\ ${ }^{5}$ Department of Pathological Anatomy, \\ Medical Faculty, Sultan Agung Islamic \\ University, Semarang \\ ${ }^{6}$ Undergraduate Student of Medical \\ Faculty, Diponegoro University \\ Semarang
}

\section{*Correspondence:}

Assoc. Prof. Dr. dr. Agung Putra M.Si. Med.

Kaligawe Raya Km. 4 Semarang, Central Java, 50112, Indonesia PO Box 1054/SM

Telp. (+6224) 6583584

Email: dr.agungptr@gmail.com ORCID ID : 0000-0003-4261-9437

Date of first submission, December 17, 2020

Date of final revised submission,

February 12, 2021

Date of acceptance, February 26, 2021

This open access article is distributed under a Creative Commons AttributionNon Commercial-Share Alike 4.0 International License 


\section{INTRODUCTION}

Liver fibrosis (LF), a most common chronic liver injury, results from unregulated wound healing. ${ }^{(1,2)}$ Transforming growth factor-beta (TGF- $\beta$ ), a cytokine released by inflammatory cells (for example macrophages), parenchymal cells, and platelets during the healing process, is the main contributor of LF promotion through activation of quiescent hepatic stellate cells (HSCs) into myofibroblasts (MFs). ${ }^{(3)}$ The active MFs are characterized by expression of $\alpha$-smooth muscle actin ( $\alpha$-SMA) and increased synthesis of the extracellular matrix (ECM) such as collagen, potentially inducing scar tissue development. ${ }^{(4-6)}$ Therefore, novel treatments to reverse fibrogenesis via TGF- $\beta$ suppression remain to be explored. On the other hand, recent studies have reported that mesenchymal stem cells (MSCs) offer a new alternative pattern in the repair and regeneration of LF that results in improved hepatocyte survival and inhibition of HSC activation. ${ }^{(7-9)}$ However, the role of MSCs in inactivating HSCs through TGF- $\beta$ has not been evaluated.

Mesenchymal stem cells (MSCs) are identified as plastic-adherent cells, which have multipotent differentiation capacity into several specific mature tissue cells including osteocytes, chondrocytes, adipocytes, and neurocytes. ${ }^{(10)}$ Mesenchymal stem cells can also express several surface markers such as CD73, CD90, CD105, CD44, while lacking the expression of CD45, CD34, CD14 or CD11b, CD79a, or CD19, and human leucocyte antigen (HLA) class II. ${ }^{(11,12)} \mathrm{A}$ previous study revealed that MSCs could preserve immunoregulatory properties including suppressing the prolonged release of TGF in liver injury. ${ }^{(5)}$ Furthermore, the improvement of LF is associated with a decreased level of TGF- $\beta{ }^{(13)}$ These statements indicate that MSCs may decrease inflammatory cell-released TGF- $\beta$ expression to induce optimum liver regeneration in LF.

Transforming growth factor $\beta$, belonging to a superfamily of cytokines and molecular agents, has a prime role in immune regulation and wound healing, including LF regeneration. ${ }^{(13,14)}$ Previous studies have demonstrated that TGF$\beta 1$ can activate HSCs into MFs leading to the synthesis of excessive amounts of matrix proteins resulting in accelerated wound healing. ${ }^{(15,16)}$ Furthermore, TGF- $\beta$ expressed by Kupffer and other proinflammatory immune cells during liver injury plays essential roles in regulating tissue development and homeostasis. ${ }^{(17)}$ However, a prolonged wound healing process could cause the aggregation of proinflammatory immune cells in liver injury, resulting in a continuous release of TGF $\beta$ that is correlated with the accumulation of collagen deposition leading to LF formation. ${ }^{(7)}$ Therefore, there is a need for the suppression of TGF- $\beta$ levels released by inflammatory cells, at the appropriate time, specifically on day 7 , that indicates the proliferation phase, by using MSCs to modulate liver regeneration without scar formation. Here lies the difference between our study and the previous studies. The aim of this study was to examine the role of MSCs in suppressing TGF- $\beta$ levels to accelerate liver regeneration in $\mathrm{LF}$.

\section{METHODS}

\section{Research design}

This experimental study was of completely randomized design to compare the treatment effects on the experimental and control groups at the end of the treatment. The research was conducted in June - August 2020 at the Stem Cell and Cancer Research (SCCR) Laboratory, Faculty of Medicine, Sultan Agung Islamic University, Semarang.

\section{Isolation of MSCs}

Mesenchymal stem cells were obtained from a single pregnant Sprague-Dawley (SD) rat under anesthesia and transplanted into an LF rat model. In brief, after removal of the blood vessels the umbilical cord was cut into pieces and then transferred to a T25 culture flask containing complete Dulbecco's Modified Eagle's medium 
(DMEM) (Sigma-Aldrich, St Louis, MO) mixed with $10 \%$ fetal bovine serum (FBS) (Gibco(TM) Invitrogen, NY, USA), and $100 \mathrm{IU} / \mathrm{mL}$ penicillin/ streptomycin (Sigma-Aldrich). Isolated cells were incubated in a $5 \% \mathrm{CO}_{2}, 37^{\circ} \mathrm{C}$ incubator and the medium was changed every 3 days. After the cells had attained $80 \%$ confluence, the MSC-like cells were passaged with trypsin. Cells from the $4^{\text {th }}$ passage were used for the experiments.

\section{Animal model for liver fibrosis}

In order to develop the liver fibrosis model, twenty-four male SD rats were injected intraperitoneally with carbon tetrachloride $\left(\mathrm{CCl}_{4}\right)$ (Sigma-Aldrich, USA) at $1 \mathrm{ml} / \mathrm{kg}$ body weight, twice weekly for 8 weeks.

\section{Administration of MSCs}

We isolated MSCs from a single rat umbilical cord and transplanted the UC-MSCs into other rats (allogeneic transplantation). The sample size in this research was determined using the Federer formula $(\mathrm{t}-1)(\mathrm{r}-1) \geq 15$ ( $\mathrm{t}=$ number of treatments; $\mathrm{r}=$ number of replications).

Therefore the size of the sample used in this study was $4 \times 4=16$ animals in which there were 4 animals in every treatment group. However, replication is required at every treatment as an alternative. Therefore the total number of animals needed was 24, such that there were 6 animals for each treatment. The experimental rats were randomly assigned into the negative $\operatorname{control}(\mathrm{n}=6)$, $\mathrm{CCl}_{4}(\mathrm{n}=6)$, and $\mathrm{CCL}_{4}+\mathrm{T} 1(\mathrm{n}=6)$ and $\mathrm{CCl}_{4}+\mathrm{T} 2$ $(n=6)$ groups. In addition, the negative controls received $\mathrm{NaCl} 0.1 \mathrm{~mL}$ twice for a week, and the treatment groups $\mathrm{T} 1$ and $\mathrm{T} 2$ received $\mathrm{CCl}_{4}$ plus MSCs at doses of $1 \times 10^{6}$ and $2 \times 10^{6}$ cells in 500 $\mu \mathrm{L} \mathrm{NaCl}$, respectively. The treatment doses were administered in $0.1 \mathrm{~mL}$ saline via tail vein injection twice for a week.

\section{Flow cytometric immunophenotyping of MSCs}

The MSC immunophenotypes were analyzed in the fourth passage. MSCs were stained with conjugated antibodies, namely fluorescein isothiocyanate (FITC)-conjugated CD90, allophycocyanin (APC)-conjugated CD73, peridinin chlorophyll protein complex (PerCP)conjugated CD105 and phycoerythrin (PE)conjugated Lin monoclonal antibodies, for $30 \mathrm{~min}$ at $4^{\circ} \mathrm{C}$ in the dark. The fluorescence intensity of the cells was evaluated through flow cytometry (BD Bioscience, Franklin Lakes, NJ, USA).

\section{In vitro differentiation}

Mesenchymal stem cell differentiation potential was determined in order to characterize the isolated cells. These cells were cultured in DMEM medium supplemented with $10 \%$ FBS, $10 \mathrm{mmol} / \mathrm{L} \beta$-glycerophospate, $10^{7} \mathrm{~mol} / \mathrm{L} / 0.1 \mu \mathrm{M}$ dexamethasone, $50 \mu \mathrm{mol} / \mathrm{L}$ ascorbate-2phosphate (all from Sigma-Aldrich, Louis St, MO), at $37^{\circ} \mathrm{C}$ and $5 \% \mathrm{CO}_{2}$. The fixed cells were stained with $0.2 \%$ Alizarin Red solution (Sigma-Aldrich) to demonstrate calcium deposition (cells used were from the fourth passage).

\section{Enzyme-linked immunosorbent assay (ELISA)}

Rat blood was harvested via periorbital venous plexus bleeding under general anesthesia on day 7 after MSC administration and the serum was collected by centrifugation at $4^{\circ} \mathrm{C}$. The TGF$\beta$ levels were measured by means of enzymelinked immunosorbent assay (ELISA) kits, based on the manufacturer's instructions (Abbkine) and according to a standard curve constructed for each assay. The colorimetric absorbance was recorded at a wavelength of $450 \mathrm{~nm}$.

\section{Statistical analysis}

All data were presented as mean \pm standard deviation with differences between groups analyzed by a one-way ANOVA and a least significant difference (LSD) comparison post hoc test. This was obtained using a $\mathrm{p}<0.05$ statistical significant value.

\section{Ethical clearance}

This study was approved by the Institutional Review Board of the Ethics Committee, Faculty 

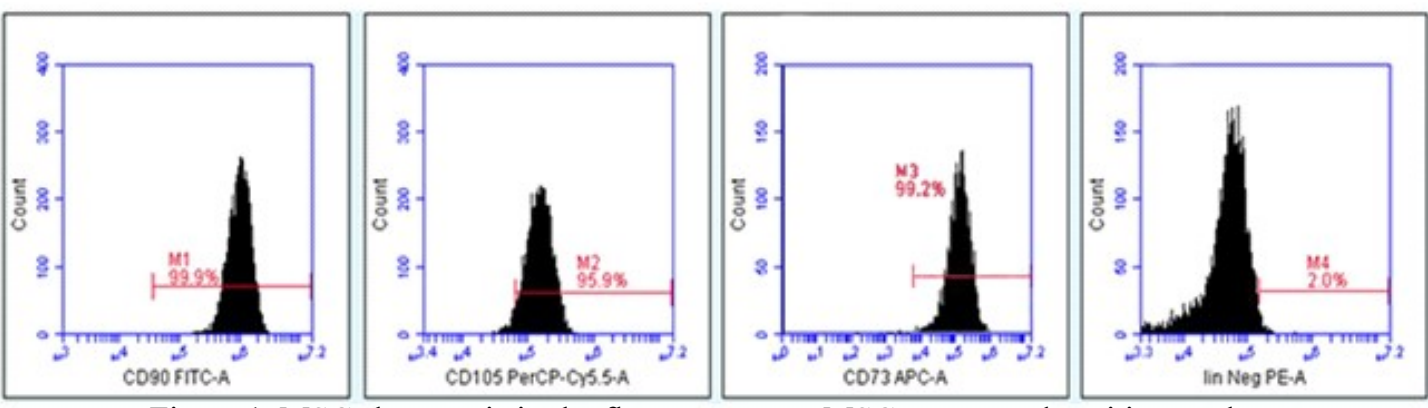

Figure 1. MSC characteristics by flow cytometry. MSCs expressed positive markers

(CD105, CD73, and CD90) and lack of Lin (Lin ).

of Medicine, Sultan Agung Islamic University, Semarang, Indonesia, under number 607/VI/2020/ Komisi Bioetik.

\section{RESULTS}

\section{Characteristics and differentiation of MSCs}

The immunophenotype characteristics of MSCs were evaluated using flow cytometric analysis to determine and verify the specific markers of MSCs. The results showed that the isolated cells expressed an MSC-specific marker profile, such as the presence of CD105 (96.7\%), CD73 (99.2\%), and CD90 (96.7\%), and lack of Lin $(0.03 \%)$ (Figure 1$)$. In line with the expression of MSC specific markers, we also analyzed MSC morphology and differentiation. MSCs were isolated by their plastic adherence capability under standard culture conditions $\left(37^{\circ} \mathrm{C}, 5 \% \mathrm{CO}_{2}\right)$ and

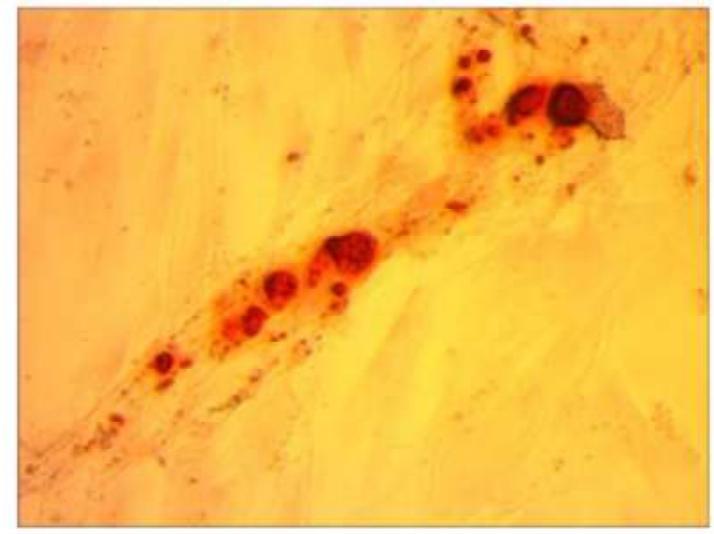

A their peculiar fibroblast-like (spindle shape) morphology (magnification x200, scale bar 100 $\mu \mathrm{m})$. The differentiation assay indicated that the multipotency of cultured MSCs was wellmaintained which was identified as calcium deposits (red color appearance) in Alizarin red staining (Figure 2). This method corresponds to the minimal criteria for MSCs of the International Society of Cellular Therapy (ISCT).

\section{Mesenchymal stem cell suppression of TGF- $\beta$ levels in $\mathbf{L F}$}

In LF, TGF- $\beta$ plays a crucial role through induction of HSC activation, whereas reduction of TGF- $\beta$ expression is correlated with LF improvement. To determine the role of MSCs in LF regeneration, we measured the TGF- $\beta$ levels using ELISA. The levels of TGF- $\beta$ in both the low and high dose MSC groups were significantly

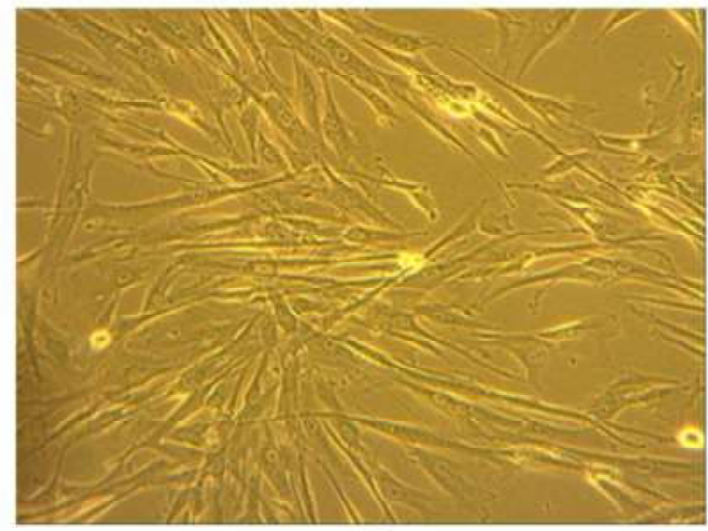

B

Figure 2. Morphology and differentiation of MSCs. (A) MSC morphology. MSCs showed a red color with Alizarin red staining (magnification x40, scale bar $50 \mu \mathrm{m}$ ). (B) MSC differentiation.

After the fourth passage, MSC differentiation showed as homogeneous, spindle-shaped, fibroblast-like cells $(200 \times$ magnification, scale bar $100 \mu \mathrm{m})$ 
Table 1. Levels of TGF- $\beta 1$ by treatment group on day 7

\begin{tabular}{lc}
\hline \multicolumn{1}{c}{ Group } & TGF- $\boldsymbol{\beta} 1(\mathbf{p g} / \mathbf{m L})($ Mean \pm SD) \\
\hline $\mathrm{NC}$ & $44.38 \pm 8.60$ \\
$\mathrm{CCl}_{4}$ & $184.31 \pm 28.55^{*}$ \\
$\mathrm{~T} 1$ & $64.07 \pm 27.53^{*}$ \\
$\mathrm{~T} 2$ & $34.1 \pm 0.74^{*}$ \\
\hline
\end{tabular}

Data were presented as the mean \pm standard deviation. ${ }^{*} \mathrm{p}<0.05 . \mathrm{NC}=$ negative control; $\mathrm{CCl}_{4}=$ Carbon tetrachloride; $\mathrm{T} 1=\mathrm{CCl}_{4}+\mathrm{MSC}$ dose of $1 \times 10^{6}$ cells; $\mathrm{T} 2=\mathrm{CCl}_{4}+$ MSC dose of $2 \times 10^{6}$ cells; TGF- $\beta 1=$ transforming growth factor- $\beta 1$.

decreased $(\mathrm{T} 1=64.07 \pm 27.53 ; \mathrm{T} 2=34.91 \pm 0.74)$ compared with the control group $(184.3 \pm 8.26)$ $(\mathrm{p}<0.05)$. The suppression capability of high dose MSCs was optimal and more significant than that of low dose MSCs. In addition, the level of TGF$\beta 1$ expression in the $\mathrm{CCl}_{4}$ group was high due to continuous inflammation.

\section{DISCUSSION}

This study showed that the TGF- $\beta$ levels of the LF rat models decreased on day 7 after MSC administration. Several studies have widely demonstrated that the potential of MSCs to regenerate diseased livers, including LF, is by inducing hepatocyte proliferation, in addition to reducing the activation of hepatocyte stellate cells (HSCs). ${ }^{(18-20)}$ The activation and differentiation of HSCs into MFs are induced by main molecular agents, particularly TGF- $\beta .^{(14,21)}$ TGF- $\beta$ is the most potent profibrotic cytokine released and activated after tissue injury, thus suppressing its expression is important in fibrotic disease. ${ }^{(21)}$ Previous studies have shown that MSCs can reduce the expression of TGF- $\beta 1$ level in fibrotic diseases. ${ }^{(13,22)}$ However, the decrease in TGF- $\beta$ expression by MSCs in LF has not been clearly explained. Therefore, in this study we investigated the MSCs' pivotal role in suppressing TGF- $\beta$ levels, leading to the decrease in collagen density in LF regeneration. To analyze the roles of MSCs in suppressing TGF- $\beta$ levels associated with collagen density in LF, we used carbon tetrachloride $\left(\mathrm{CCl}_{4}\right)$-injected Sprague-Dawley rats to induce an established LF animal model, according to previous protocols.

In our study, the decrease in TGF- $\beta 1$ levels occurring in LF might be controlled by MSC administration through the release of antiinflammatory cytokines, primarily interleukin 10 (IL-10). As a potent anti-inflammatory cytokine, IL-10 could prevent fibrosis progression by competitively binding to TGF- $\beta$ receptors resulting in the reduction of TGF- $\beta$ expression. Currently, MSCs can suppress TGF- $\beta$ levels released by M2 macrophages through release of IL-10..$^{(9,23)}$ We suggest that the decrease in TGF by IL-10 occurs through the binding of IL-10 to Kupffer receptors that activate Janus tyrosine kinase 1 (JAK1) and tyrosine kinase-2, leading to signal transduction and activation of transcription 3 (STAT3) which then migrates to the nucleus and binds to the target gene promoter, resulting in the suppression of TGF- $\beta$ expression. ${ }^{(9,24,25)}$ In

Table 2. Post-hoc LSD test for levels of TGF- $\beta 1$ expression between study groups

\begin{tabular}{ccccc}
\hline \multirow{2}{*}{ Group } & Comparison group & Significance & \multicolumn{2}{c}{ 95\% Confidence Interval } \\
\cline { 4 - 5 } $\mathrm{NC}$ & $\mathrm{CCl}_{4}{ }^{*}$ & 0.01 & Lower limit & Upper limit \\
& $\mathrm{T} 1$ & 0.27 & -178.06 & -101.77 \\
& $\mathrm{~T} 2$ & 0.58 & -57.83 & 18.46 \\
$\mathrm{CCl}_{4}$ & $\mathrm{~T} 1^{*}$ & 0.01 & -28.67 & 47.62 \\
& $\mathrm{~T}^{*}$ & 0.01 & 82.09 & 158.38 \\
$\mathrm{~T} 1$ & $\mathrm{~T}^{*}$ & 0.04 & 111.25 & 187.54 \\
\hline
\end{tabular}

Significance $\mathrm{p}<0.05 ; \mathrm{NC}=$ negative control; $\mathrm{CCl} 4=$ Carbon tetrachloride; $\mathrm{T} 1=\mathrm{CCl} 4+\mathrm{MSC}$ dose of $1 \times 10^{6}$ cells; $\mathrm{T} 2=$ $\mathrm{CCl} 4+\mathrm{MSC}$ dose of $2 \times 10^{6}$ cells 
addition, the increased TGF- $\beta$ levels in the control group may be due to the lack of IL-10 that is released by MSCs to suppress the TGF- $\beta$ levels, consequently, the TGF level increases because the inflammation has not been controlled. On the other hand, the decrease in TGF may also be effected by blocking the SMAD pathway. ${ }^{(24)}$

In regard to the Janus tyrosine kinase 1 (JAK1) pathway to suppress TGF, IL-10 also blocks the SMAD pathway. The interaction of IL-10 with the TGF $\beta$-receptor induces serine/ threonine kinase activity, leading to the induction of the downstream signaling proteins SMAD2 or SMAD3. This results in the inhibition of the expression of fibrotic genes, such as $\alpha$-SMA, collagen and fibronectin. ${ }^{(26-28)}$ This is supported by a previous study that reported that increased IL-10 induces SMAD7, resulting in downregulation of the SMAD2/SMAD3 pathway. ${ }^{(29)}$ Thus, we believe that blocking the binding of TGF $\beta$-receptors by IL-10 released MSCs may be associated with decreased TGF$\beta$ expression leading to LF improvement. Overall, the implication of this study may be useful for research on the potential of stem cells to accelerate and direct target screening through molecular mechanisms to treat fibrosis in chronic liver injury. A limitation of this study is that we did not examine IL-10 as a competitive receptor to TGF- $\beta$ associated with JAK1 and SMADs. In addition, we also did not analyze the collagen density as a fibrosis indicator in the LF animal model. Therefore, for future directions, understanding the role of IL-10 secreted by MSCs to suppress TGF- $\beta$ expression in association with the decrease in collagen remains to be explored.

\section{CONCLUSIONS}

We conclude that MSCs can suppress the TGF- $\beta$ levels in LF induced rats. This study provides new insights into the benefits of UCMSCs administration in most injured tissues, particularly in the proliferation phase in liver fibrosis.

\section{CONFLICT OF INTEREST}

The authors report no conflicts of interest. The authors are responsible for the content and writing of this article.

\section{ACKNOWLEDGMENT}

We would like to thank the Stem Cell and Cancer Research (SCCR) Laboratory, the Faculty of Medicine, Sultan Agung Islamic University (UNISSULA), Semarang, Indonesia and all who contributed to this research.

\section{CONTRIBUTORS}

NACS and AP did the concept and design of the work. BTD and NH built the database and did the data collection. SYA and RCSI did all the analysis and interpretation. AP supervised the study and critically revised the article. All authors have read and approved the final manuscript.

\section{REFERENCES}

1. Bert F. Liver fibrosis: difficulties in diagnostic and treatment: a review. Gastroenterol Med Res 2017;1:1-8. doi : 10.31031/GMR.2017.01.000502.

2. He Z, Yang D, Fan X, et al. The roles and mechanisms of lncRNAs in liver fibrosis. Int $\mathbf{J}$ Mol Sci 2020;21:1-19. doi: 10.3390/ijms21041482.

3. Jiang F, Liu GS, Dusting GJ, Chan EC. NADPH oxidase-dependent redox signaling in TGF- $\beta$ mediated fibrotic responses. Redox Biol 2014;2:267-72. doi: 10.1016/j.redox.2014.01.012.

4. Chan YT, Wang N, Tan HY, Li S, Feng Y. Targeting hepatic stellate cells for the treatment of liver fibrosis by natural products: is it the dawning of a new era? Front Pharmacol 2020;11:1-16. doi: 10.3389/fphar.2020.00548.

5. Fabregat I, Caballero-Díaz D. Transforming growth factor- $\beta$-induced cell plasticity in liver fibrosis and hepatocarcinogenesis. Front Oncol 2018;8;357. doi : 10.3389/fonc.2018.00357.

6. Chobert MN, Couchie D, Fourcot A, et al. Liver precursor cells increase hepatic fibrosis induced by chronic carbon tetrachloride intoxication in rats. Lab Investig 2012;92:135-50. doi : 10.1038/ labinvest.2011.143.

7. Hu C, Zhao L, Duan J, Li L. Strategies to improve the efficiency of mesenchymal stem cell 
transplantation for reversal of liver fibrosis. J Cell Mol Med 2019;23:1657-70. doi: 10.1111/ jcmm.14115.

8. Van De Walle GR, De Schauwer C, Fortier LA. Mesenchymal stem cell therapy. In: MJB Felippe, editor. Equine Clinical Immunology. WileyBlackwell; 2016. pp. 297-310.

9. Sungkar T, Putra A, Lindarto D, Sembiring RJ. Intravenous umbilical cord-derived mesenchymal stem cells transplantation regulates hyaluronic acid and interleukin-10 secretion producing lowgrade liver fibrosis in experimental rat. Med Arch (Sarajevo, Bosnia Herzegovina) 2020;74:177-82. doi: 10.5455/medarh.2020.74.177-182.

10. Lai P, Weng J, Guo L, Chen X, Du X. Novel insights into MSC-EVs therapy for immune diseases. Biomark Res 2019;7:1-10. doi: 10.1186/ s40364-019-0156-0.

11. Thitilertdecha P, Lohsiriwat V, Poungpairoj P, et al. Extensive characterization of mesenchymal stem cell marker expression on freshly isolated and in vitro expanded human adipose-derived stem cells from breast cancer patients. Stem Cells Int 2020;2020. doi: 10.1155/2020/8237197.

12. Numakura S, Uozaki H, Kikuchi Y, Watabe S, Togashi A, Watanabe M. Mesenchymal stem cell marker expression in gastric cancer stroma. Anticancer Res 2019;39:387-93. doi : 10.21873/ anticanres.13124.

13. Sabry D, Mohamed A, Monir M, Ibrahim HA. The effect of mesenchymal stem cells derived microvesicles on the treatment of experimental CCL4 induced liver fibrosis in rats. Int J Stem Cells 2019;12:400-9. doi : 10.15283/ijsc18143.

14. Dewidar B, Soukupova J, Fabregat I, Dooley S. TGF- $\beta$ in hepatic stellate cell activation and liver fibrogenesis: updated. Curr Pathobiol Rep 2015;3:291-305. doi: 10.3390/cells8111419.

15. Koyama Y, Xu J, Liu X, Brenner DA. New developments on the treatment of liver fibrosis. Dig Dis 2016;34:589-96. doi: 10.1159/000445269.

16. Kim KK, Sheppard D, Chapman HA. TGF- $\beta 1$ signaling and tissue fibrosis. Cold Spring Harb Perspect Biol 2018;10. doi: 10.1101/ cshperspect.a022293.

17. Li SN, Wu JF. TGF- $\beta /$ SMAD signaling regulation of mesenchymal stem cells in adipocyte commitment. Stem Cell Res Ther 2020;11:1-10. doi: 10.1186/s13287-020-1552-y.

18. El Agha E, Kramann R, Schneider RK, et al. Mesenchymal stem cells in fibrotic disease. Cell Stem Cell 2017;21:166-77. doi: 10.1016/ j.stem.2017.07.011.

19. Haldar D, Henderson NC, Hirschfield G, Newsome PN. Mesenchymal stromal cells and liver fibrosis: a complicated relationship. FASEB J 2016;30:3905-28. doi: 10.1101/ cshperspect.a022293.

20. Putra A, Antari AD, Kustiyah AR, et al. Mesenchymal stem cells accelerate liver regeneration in acute liver failure animal model. Biomed Res Ther 2018;5:2802-10. doi: 10.15419/ bmrat.v5i11.498.

21. Putra A, Ridwan FB, Putridewi AI, et al. The role of TNF- $\alpha$ induced MSCs on suppressive inflammation by increasing TGF- $\beta$ and IL- 10 . Open Access Maced J Med Sci 2018;6:1779-83. doi: 10.3889/oamjms.2018.404.

22. Lv S, Liu G, Sun A, et al. Mesenchymal stem cells ameliorate diabetic glomerular fibrosis in vivo and in vitro by inhibiting TGF- $\beta$ signalling via secretion of bone morphogenetic protein 7 . Diabetes Vasc Dis Res 2014;11:251-61. doi: 10.1177/1479164114531300.

23. Sungkar T, Putra A, Lindarto D, Sembiring RJ. The effect of mesenchymal stem cells for the reduction of liver fibrosis through platelet derived growth factorâ regulation in rats. Biochem Cell Arch 2019;19:4749-53. doi:10.35124/ bca.2019.19.S2.4749.

24. Sziksz E, Pap D, Lippai R, et al. Fibrosis related inflammatory mediators: role of the IL-10 cytokine family. Mediators Inflamm 2015;2015:764641. doi: 10.1155/2015/764641.

25. Fathy M, Okabe M, Eldien HMS, Yoshida T. ATMSCs antifibrotic activity is improved by eugenol through modulation of TGF- $\beta /$ Smad signaling pathway in rats. Molecules 2020;25:1-17. doi: 10.3390/molecules25020348.

26. Duan D, Derynck R. Transforming growth factor$\beta$ (TGF- $\beta$ )-induced up-regulation of TGF- $\beta$ receptors at the cell surface amplifies the TGF- $\beta$ response. J Biol Chem 2019;294:8490-504. doi: 10.1074/jbc.RA118.005763.

27. Xu F, Liu C, Zhou D, Zhang L. TGF- $3 /$ SMAD pathway and its regulation in hepatic fibrosis. $\mathrm{J}$ Histochem Cytochem 2016;64:157-67. doi:10.1369/0022155415627681.

28. Xu Y, Tang X, Yang M, et al. Interleukin 10 genemodified bone marrow-derived dendritic cells attenuate liver fibrosis in mice by inducing regulatory $T$ cells and inhibiting the TGF- $\beta / \mathrm{Smad}$ signaling pathway. Mediators Inflamm 2019;2019: 4652596. doi: 10.1155/2019/4652596.

29. Shi CK, Zhao YP, Ge P, Huang GB. Therapeutic effect of interleukin-10 in keloid fibroblasts by suppression of TGF- $\beta /$ Smad pathway. Eur Rev Med Pharmacol Sci 2019;23:9085-92. doi: 10.26355/eurrev_201910_19311. 